\section{Electrophoretic Patterns of Mealworm Proteins}

THE literature concerning insect proteins is, generally, represented by analyses of single developmental stages, usually immature, hæmolymph being the principal fluid investigated. The results of these studies show that the protein component fluctuates during development ${ }^{1-4}$. This communication shows the variations for the protein component of the mealworm Tenebrio molitor, during its developmental stages. The method employed, electrophoresis, seems to be a useful facility for investigations of this nature, since electrophoretic patterns of proteins are distinctive. Specific pattern characteristics have been reported for developmental stages of mammals, closely related species of reptiles ${ }^{6,7}$, and amphibians ${ }^{8,9}$.

The insects were raised in the laboratory on a diet of chicken mash and grain and a daily ration of water. Eggs, laid in white flour, were harvested daily, and white larvæ, pupæ and adults were collected within one hour following their emergence. In this manner timed records were maintained for each phase of the life-cycle. Approximately $100 \mathrm{mgm}$. of eggs, newly emerged and 14-day-old larvæ were separately homogenized in $1 \mathrm{ml}$. of water in a tissue homogenizer. The posterior abdominal segment of pupæ and aduits was severed and the body contents extruded into separate weighing vials containing $1 \mathrm{ml}$. of water until $100 \mathrm{mgm}$. had been collected. The samples were centrifuged and the supernates retained for electrophoresis. $0.02-\mathrm{ml}$. volumes of extract were applied to Whatman No. 1 filter paper strips for

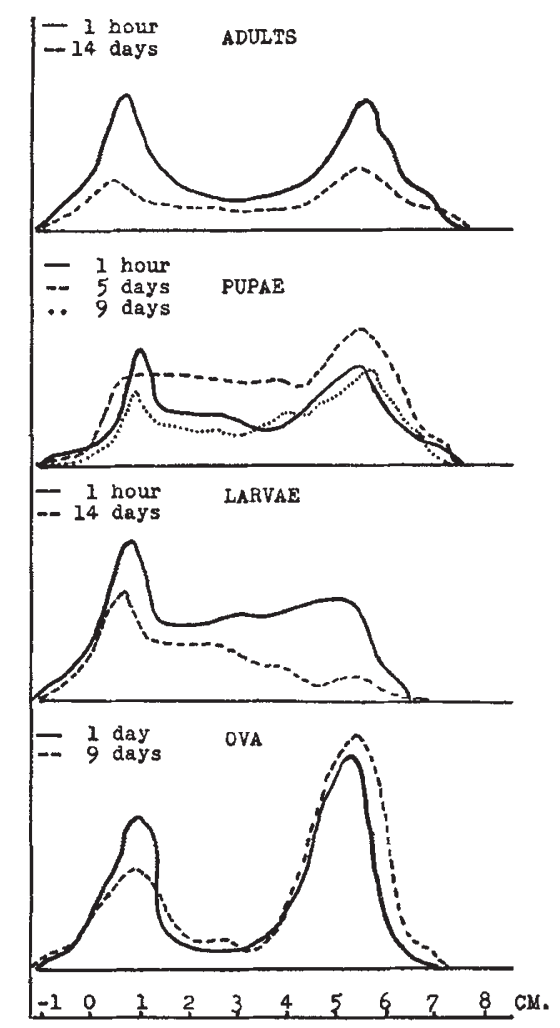

Fig. 1. Paper electrophoresis patterns of the mealworm Tenebrio molitor, at various stages of development. Extract, $0.02 \mathrm{ml}$., was applied at $0 \mathrm{~cm}$.; anode is to the right analysis ('Spinco' electrophoretic system, barbital buffer $p \mathrm{H} 8 \cdot 6$, ionic strength $0 \cdot 05,5$ m.amp., $16 \mathrm{hr}$.). The strips were dried at $120^{\circ} \mathrm{C}$. for 30 min., stained with light green $S F^{10}$ and scanned with a recording densitometer ('Spinco Analytrol').

The electrophoretic patterns in Fig. I show two distinct anodal fractions for all stages except the 14-day-old larvæ. The slower migrating fraction shows a well-defined band between -1 and $1 \mathrm{~cm}$. from the point of origin. The faster fraction is well resolved between 4 and $6 \mathrm{~cm}$. from the point of origin.

A comparison of the four stages discloses a uniformity in pattern for the slow fraction. Its concen. tration decreased as each phase of the developing mealworm progressed towards maturity. The fast fraction patterns are more variable. The peak is greater than that of the slow fraction for the egg and 5-day-old pupæ, approximately equal for the adults and the 9-day-old pupæ, and lower for the remaining groups. The eggs and pupæ also show alternation of the high peaks for the two fractions during their respective growth periods. A similar pattern prevails for the 1-hr. and 5-day-old pupæ. The trough separating the two peaks is relatively low for the ova and adults. The mid-pattern of the pupæ depicts a distinct rise and fall in concentration with increasing age.

These results show, generally, the direction of change for each stage of development and suggest the influence of basic growth activities. The results display the same type of variation as do morphological and physiological factors in bringing about protein changes in response to a modification of immature tissues for the subsequent building of the mature structure.

This study suggests the value of paper electrophoresis in revealing characteristics of insect proteins for investigating the comparative physiology of life-cycle activities.

\section{S. Po-Chediey}

D'Youville College,

Buffalo, 1,

New York.

Oct. 17.

1 Heller, J., C.R. Soc. Biol, Paris, 90, 1360 (1924).

${ }^{2}$ Ludwig, D., and Rothstein, F., Phys. Zoöl., 25, 263 (1952).

${ }^{3}$ Ludwig, D., Phys. Zoöl., 27, 325 (1954).

${ }^{4}$ DelVecehio, R. J., J. New York Ent. Soc., 63, 141 (1955).

5 Barboriak, J. J., Meschia, G., Barron, D. H., and Cowgill, G. R., Proc. Soc. Exp. Biol. and Med., 98, 635 (1958).

- Rutquist, L., Amer. J. Vet. Res., 19, 25 (1958).

'Dessauer, H. C., and Fox, W., Proc. Soc. Exp. Biol. and Med., 98, 101 (1958).

${ }^{8}$ Deutsch, H. F., and MeShan, W. H., J. Biol. Chem., 180, 219 (1949).

- Dessauer, H. C., and Fox, W., Science, 124, 225 (1956).

${ }^{10}$ Rideout, L. A., and Prichard, R. W., Science, 121. 374 (1955).

\section{Environmental Temperature and the Reptilian Nervous System}

Ir has been found that the terminal plexus of the reptilian brain undergoes marked changes with the environmental temperature.

Lizards (Lacerta viridis) have been kept at $19^{\circ} \mathrm{C}$. and at $32 \pm 3^{\circ} \mathrm{C}$. for periods up to 8 weeks. Some of the animals (twenty-four) were killed by perfusion with saline followed by 10 per cent neutralized formol saline under ether or urethane anæsthesia, and the brains were prepared by the Holmes method. Other 